\title{
PARENTAL INVOLVEMENT OF INDONESIAN SENIOR HIGH STUDENTS: CONTRIBUTION TOWARDS ACADEMIC SUCCESS
}

\author{
Fathor Rasyid \\ State College for Islamic Studies, Kediri, Indonesia \\ frasyid@yahoo.com
}

\begin{abstract}
The research was carried out to investigate whether there was any significant contribution of family background and parental involvement towards students' achievement, and which spesific parental involvement aspects best predict students English performance. To this end, English test was administered to Indonesian senior high school students $(n=222)$, and questionnaire was to their parents. Path analysis with smart PLS was utilized to analyze the data. The results revealed that the contribution of family background towards parental involvement is significant. However, there are no significant contributions of parental involvement and family background towards students' achievement. No significant contribution is also found between family background and students' achievement through intermediary variable of parental involvement. Other finding indicated that parents' aspiration and expectation along with enhancing learning opportunities at home had the strongest effects on students' achievement.
\end{abstract}

Keywords

Parental involvement, students performance, family background, learning opportunities

\section{INTRODUCTION}

In recent years, due to the development of sociology of education, the role of parents has long been thought to be centrally important to the academic achievement of their children. There is a plethora of evidence revealing that parental involvement in education is associated with positive gains in children's academic and cognitive outcomes as well as English achievement (Banerjee et al., 2011; Christenson et al., 2005; Desforges \& Abouchaar, 2003; Graves \& Wright, 2011; Henry et al., 2011; Hornby, 2011; Jaynes, 2011; Jeynes, 2003, 2005, 2007; Katzet et al., 2011; Rachmajanti, 
2005). Jaynes (2011) and Hornby, (2011) conclude that children who have highly involved parents have better academic outcomes in elementary and secondary education. Further, Henderson and Mapp (2002) as well as Grant and Ray (2010) highlighted that the most effective schools are widely considered to be ones that encourage and support the involvement of parents and other family members in the education of their children.

The merits of parental involvement that emerge from the above reviews encompass benefits for children, teachers, and parents. For children, involvement of their parents is reported to lead to improvements in children's attitudes, behavior, and attendance at school, as well as in their mental health. For teachers, effective parental involvement is reported to improve parent-teacher relationships, teacher morale, and the school climate. For parents, involvement in their children's education has been linked to increased parental confidence in and satisfaction with parenting, as well as increased interest in their own education. However, many questions have been raised about the quality and the quantity of parental involvement in their children's education.

Important findings from the previously-mentioned research are that the effectiveness of parental involvement in bringing better achievement applies across gender and ethnic groups and that this also applies across the age range, including children at elementary, middle, and secondary schools (Bowden et al., 2005; Butler, 2000; Christenson et al., 2005 ; McBride et al., 2005;). Breault \& Allen (2008) and Bhatia (2010) ably capped it by asserting that the more intensively parents are involved in their children's learning, the more beneficial are the achievement effects. Thus, it is believed that when parents monitor homework, encourage participation in extracurricular activities, are active in parents-teacher associations, and help children 
develop plans for their future; children are more likely to respond and do well in school.

\section{LITERATURE REVIEW}

\section{Conceptualizing Parental Involvement}

Parental involvement is simply defined as how much interested, knowledgeable, and active the parents are in their children's life. Yet, the number and the sorts of parental involvement variables differ among experts. For instance, Singh et al. (1995) identified four components of parental involvement namely: parental aspirations for children's education, parentchild communication about school; home-structure and parental participation in school related activities. It should be emphasized that "parental aspiration" refers to the parents' hopes and expectations on the child's continuing education, "parent-child communication" refers specifically to school related matters, "home structure" refers to the degree of discipline exerted by the parents to insist on homework completion and to limit potentially distracting activities (e.g. watching T.V.) whilst "parental participation in school" refers to parents' support for and participation in school and class functions.

Similar to Singh et al., Jeynes (2011) defines parental involvement as parental participation in the educational processes and experiences of their children. This includes home-based parental involvement, such as listening to children read and supervision of homework, as well as school-based parental involvement, such as attending parent education workshops and parentteacher meetings. The use of the term "parental" typically denotes any person who is in a parenting role with children. This includes mothers, fathers, grandparents, and other members of the extended family, as well as 
foster parents and others who are acting as guardians. Involvement in educational activities can include enriching the home environment by helping children plan time for homework or checking homework assignments (Banerjee et al., 2011). Grolnick et al., (1997) state that parental involvement concerns devoting resources to children that is, being available to them, knowledgeable about their lives, and concerned about what is going on for them.

\section{Parental Involvement and SES}

One most influential factor related to the quality of parental involvement is family background, or usually referred to family socioeconomic status (SES). It is a construct that captures various dimensions of social position, including prestige, power, and economic wellbeing (Caro, 2009). However, most contemporary investigators agree that the three quantitative indicators provide reasonably good coverage of the construct. They are education, occupation, and income. Despite the fact that these indicators of social position are positively correlated, there is also general agreement that they should not be combined into simple composite scores (Conger and Conger, 2008). Income, education, and occupational status are not interchangeable indicators of SES. Only by including each of them as a separate variable in data analyses can investigators begin to understand their unique and combined contributions to human development.

Indeed, education, occupation, and income represent separate related personal, social, and economic resources that have important implications for the health and wellbeing of both parents and children. These resources can be thought of as "capital" that differentiates persons, households, neighborhoods (Caro, 2009). As an illustration, Caro (as cited in Coleman, 1990), proposes that SES should be defined in terms of material or financial 
capital (economic resource), human capital (knowledge and skills), and social capital (connections to and the status and power of individuals in one's social network). Income and other forms of wealth obviously relate to material or financial capital and education to human capital. Although the connection is not as straightforward for occupational status, it can be considered a marker of social capital inasmuch as people in higher-status occupations are more likely to associate with others who have higher-than-average occupational status, advanced skills, and economic resources (Caro, 2009). The point is that each aspect of SES may have an important independent influence on how children are raised and on how they develop over time.

There are several reasons to suggest that the influence of SES on children and adolescents may result from the actions or behaviors of parents. For example, lower SES compared with middle SES parents are more likely to use a harsher, more authoritarian, parenting styles as indicated by physical punishment and the absence of reasoning with children about the consequences of their behavior (Casanova et al., 2005; Chasek \& Rosen, 2011). These parenting practices have been linked to less competent social and emotional development for children and adolescents (e.g., Caro, 2009). With regard to cognitive functioning, middle- compared with lower- SES parents are more likely to use richer vocabulary and to engage in cognitively stimulating activities with their children. Thus, current evidence suggests that SES is associated with important family socialization practices and with the health and well-being of children.

Another example is about homework. It is assigned on the assumption that parents or other elder members have the capacity to assist the pupils and that home environment is conducive for the pupil to do homework. Thus, homework completion depends very much upon SES and 
parents involvement either to assist or to provide conducive environment, or both. In this instance, a study conducted by Ogoye et al. (2007) on parental participation on pupils' homework shows that although parental willingness to be involved in pupils' homework is high, this involvement is hampered by many socio-economic factors, including illiteracy and low income. On many occasions, homework is not only incomplete, but also not done, and the pupils are consequently punished for this.

\section{RESEARCH METHOD}

By using multistage sampling technique, the researcher first sampled the level sites of senior high schools in Malang city, Indonesia randomly. 11th graders were used as the participatas of the study. There are 19 natural science classes, and 11 social classes. Proportional stratification is employed to get fair and appropriate proportion from each program. By referring to the table about sample size proposed by Cohen et al. (2007), taking 222 samples from 1287 population has been considered to meet the confident level of $95 \%$. Of 222, 128 students were in natural science program, and 94 in social science program. There were 95 male students and 127 female students.

The questionnaire is of two parts. The fisrts part is to elicit family background containing five questions, while the second to elicit parent involvement containing 49 items. Two experts rated the questionaire qualitatively and quantitatively for conceptual purposes. The inter-rater relaibility of the two experts is indicated by the value of kappa (.825) meaning high reliability of the two raters. Then, try-out was done for while empirical purposes. The analysis was accomplished through Confirmatory Factor Analysis. Having done the analysis, it is found that the relaibility is high with Cronbach Alpha $>.70$ (.961). The analysis on contruct validity shows that 
the values of Anti-image Correlation of each item range from .789 to .948 meaning that the values of Measures of Sampling Adequacy-MSA are much greater than .30; and therefore, all items of the questionnaire could be used to elicit the intended data.

Expert validition and try-out were employed to check the quality of the test. Of 60 items of the test, only 39 items are valid. The Cronbach's Alpha is .721 indicating that the test is reliable. The values of Anti-image Correlation of each item range from .331 to .772 meaning that the values of Measures of Sampling Adequacy_-MSA are much greater than .30; and therefore, the test with 39 items has good construct validity.

222 students did the test during class time midway through the first semester. The students were informed that the survey would have no effect on their grade. The questionnaire was given to the students (sample) for their parents to fill in. They were given two weeks to fill in and handed in to the English teachers at the schools.

Of 222 questionnaires distributed, 200 were returned, and 7 were incomplete, and consequently illegible for further analysis. That is to say, 193 questionnaires were collected and completely carried out. The path diagram in the study is constructed through the help of software smartPLS v.2.0, while further analysis of the data is analyzed by software PLS-Graph v.2.0. Since SmartPLS does not provide values indicating the indirect effect of the independent variable (family background) to dependent variable (students' English achievement), Sober Test that can be downloaded from http://quantpsy.org/sobel/sobel.htm, with this formulae z-value $=$ $a^{*} b / \mathrm{SQRT}\left(b^{2} s_{\mathrm{a}}{ }^{2}+a^{2} *_{\mathrm{b}}{ }^{2}\right)$ is used. The description of the data was summarized in Table 1 (Parents' Education), Table 2 (Parents' Income), Table 3 (Parents' SES), and Table 4 (Students' Characteristics). 
Table 1 Parents' Education

\begin{tabular}{lcccc}
\hline \multirow{2}{*}{ Education } & \multicolumn{2}{c}{ FATHERS } & \multicolumn{2}{c}{ MOTHERS } \\
& Frequency & $\%$ & Frequency & $\%$ \\
\hline Elementary & 3 & 1.6 & 4 & 2.1 \\
Junior High & 4 & 2.1 & 5 & 2.6 \\
Senior High & 51 & 26.4 & 74 & 38.3 \\
Diploma & 8 & 4.1 & 24 & 12.4 \\
Undergraduate & 68 & 35.2 & 69 & 35.8 \\
Masters & 43 & 22.3 & 12 & 6.2 \\
Doctors & 11 & 5.7 & 2 & 1.0 \\
\hline
\end{tabular}

\section{Table 2 Parents' Income}

\begin{tabular}{lcccc}
\hline \multirow{2}{*}{ Income } & \multicolumn{2}{c}{ FATHERS } & \multicolumn{2}{c}{ MOTHERS } \\
& Frequency & $\%$ & Frequency & $\%$ \\
\hline$>$ 1 million & 10 & 5.2 & 33 & 17.1 \\
1-2 millions & 32 & 16.6 & 23 & 11.9 \\
$2-3$ millions & 41 & 21.1 & 26 & 13.5 \\
$3-4$ millions & 27 & 14.0 & 11 & 5.7 \\
$4-5$ millions & 22 & 11.4 & 10 & 5.2 \\
5 millions $<$ & 44 & 22.8 & 11 & 5.7 \\
\hline
\end{tabular}

Table 3 Parents' SES

\begin{tabular}{lll}
\hline & Frequency & $\%$ \\
\hline High SES & 55 & 28.5 \\
Middle SES & 101 & 52.3 \\
Low SES & 37 & 19.2 \\
\hline
\end{tabular}


Table 4 Students' Characteristics

\begin{tabular}{llllllll}
\hline NATURAL & $\%$ & SOCIAL & $\%$ & MALE & $\%$ & FEMALE & $\%$ \\
\hline 108 & 55.9 & 85 & 44.1 & 86 & 44.6 & 107 & 55.4 \\
\hline
\end{tabular}

\section{FINDINGS AND DISCUSSION}

Having checked the outer model (composite reliability and convergent validity), through Partial Least Square with Software SmartPLS, the inner model as in Figure 1 was attained. It describes the overall path coefficients among variables and indicators.

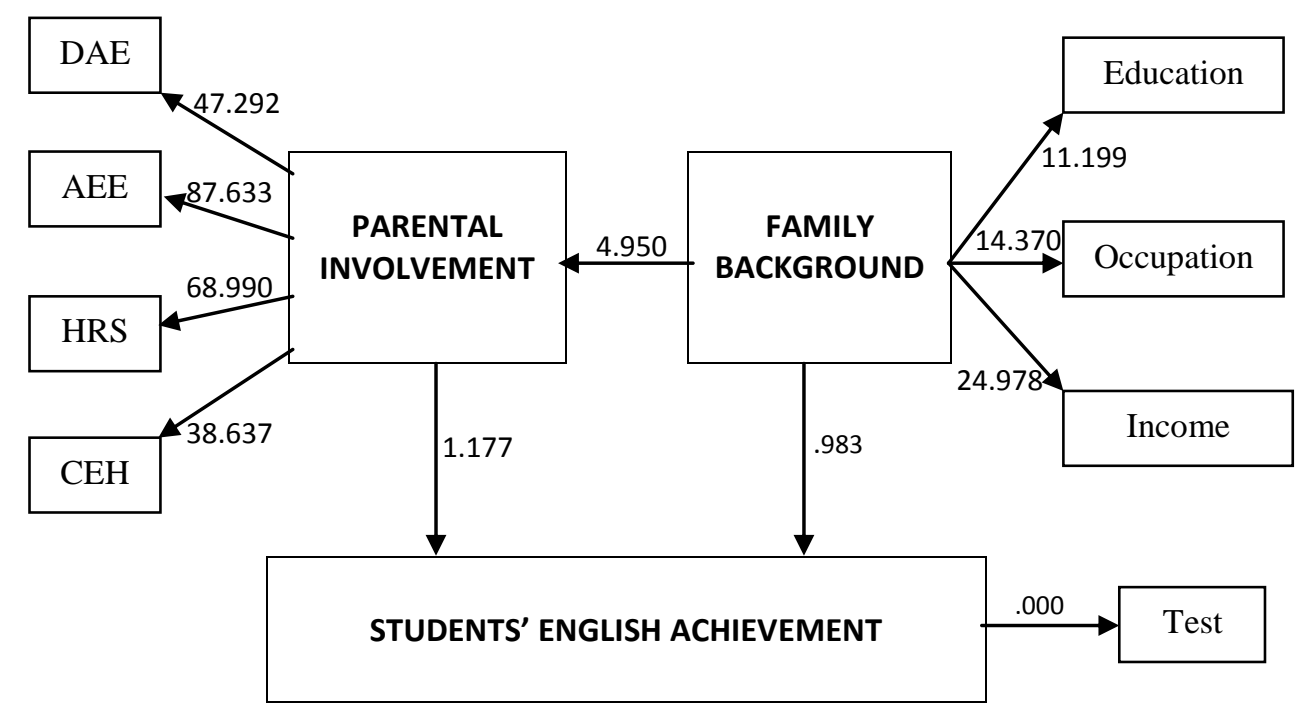

Figure 1 Structural Equation of Path Diagram

Notes:

DAE $=$ Discussing Activities about English

$\mathrm{AEE}=$ Aspiration and Expectation about English

HRS $=$ Home Rules and Supervision

$\mathrm{CEH}=$ Checking English Homework 
Figure 1 reveals that the path coefficient of the direct contribution of parents' background to parental involvement is 4.950, greater than 1.28 $(10 \%)$. It means that there is sufficient evidence to state that the contribution is significant. The path coefficient of the direct contribution of parental involvement to students' English achievement is 1.177, lower than 1.28 $(10 \%)$. It means that there is no enough evidence to utter that the contribution is significant. That is, the contribution of parental involvement to students' English achievement is not significant. Finally, The path coefficient of the direct contribution of parents' background to students' English achievement is .983 , lower than $1.28(10 \%)$. It means the contribution is not significant.

Model of contruct evaluation uses $R$-square $\left(R^{2}\right)$ for independent construct. The value of $\mathrm{R}$-square $\left(\mathrm{R}^{2}\right)$ reflects the strength of prediction from the overall model, in which the value of $\mathrm{R}$-square $\left(\mathrm{R}^{2}\right)$ should be greater than .10 or greater than $10 \%$ (goodness of fit). It was found out that the strength of prediction of $Z$ to the overall model is .016 or $1.6 \%$, meaning that $98.4 \%$ is influenced by other factors beyond the model; while the strength of prediction of $\mathrm{Y}$ to the overall model is .085 or $8.5 \%$, meaning that $91.5 \%$ is influenced by other factors beyond the model.

The Predictive Relevance Stone-Geiser Q-Square is intended to test the power of predictive relevance of the model. In this instance, the value of $R^{2}$ is then inserted into the following $Q$-square equation:

$$
\begin{aligned}
& \mathrm{Q}^{2}=1-(1-\mathrm{R} 21)(1-\mathrm{R} 22)(1-\mathrm{R} 23) \ldots(1-\mathrm{R} 2 \mathrm{n}) \\
& \mathrm{Q}^{2}=1-(1-0.016)(1-0.085)=.099
\end{aligned}
$$

When the value of Q-Square is greater than 0 (zero), it indicates that the model has predictive relevance, while less than 0 (zero), the model does not have predictive relevance (Ghozali, 2006). The Q-Square value (0.099) indicates 
that the model has predictive relevance, since the value is greater than 0 (zero), meaning that the model is good to use.

\section{Contribution of Family Background (SES) to Parental Involvement}

The present study investigates the contribution of family social economic status indicated by SES towards parental involvement in their children's English achievement. The findings of the study suggest that parents' background as indicated by their education, occupation and income contributes significantly to parental involvement with a path coefficient of 4.950. This finding is corroborated by other research findings. In an ethnographic study of parental involvement, Shannon (1996) contrasted the behavior and attitudes of high-status parents and low-status parents. She found that high-status parents assume a more proactive role while low-status parents' participation is passive. That is to say, low-income families are likely to have lower parental involvement (Hoover-Dempsey et al. 2005). This may be, up to a point, because of their lack of home resources and social support. There may be some psychological stress resulting from certain hardship occurring (Reynolds, 1992).

Generally, there are many possible factors that influence parental involvement in their child's life and education and these include gender or role and role efficacy, SES, family structure, family culture, education level, and perceptions of involvement (Hoover-Dempsey et al. 2005). In addition, Cheung and Andersen (2003) reported on both family structure and SES as predictors of parent involvement and child academic outcome. These authors noted that children from high status backgrounds have more economic resources and higher levels of cultural capital. Eventually, James (2008) and Stewart (2008) found that parent race/ethnicity, parent education level, 
parent SES, and parent perceptions of involvement, were all significantly related to parental involvement; and perceptions of involvement, SES, parent education, and relationship with student (biological mother or father) significantly predict parental involvement.

\section{Contribution of Family Background to Students' Achievement}

Even though most research findings reviewed indicate that social economic status indicated by parents' income, education and occupation, becomes one important predictor of students' achievement, the finding of the research shows that the contribution of family background (with path coefficient of .983) is not statistically significant to the students' English achievement. Similar finding was provided by McIntosh (2008). His study showed optimistic findings. That is, children from disadvantaged families are not condemned to be at the bottom of the grade distribution. In fact, children with poorly educated fathers can actually do better than average if their parents have positive attitudes on the importance of school grades and further education. Put simply, the most accurate predictor of students' achievement is not income or social status, but the extent to which those students' families are able to create a home environment that encourages learning, and express high (but not unrealistic) expectations for their children's achievement.

Another possible explanation of the finding is that there is general agreement that income, occupation and education should not be combined into simple composite scores (Conger and Conger, 2008). Income, education, and occupational status are not interchangeable indicators of SES. Only by including each of them as a separate variable in data analyses can investigators begin to understand their unique and combined contributions 
to human development. Indeed, education, occupation, and income represent separate related personal, social, and economic resources that have important implications for the health and wellbeing of both parents and children.

The point is that each aspect of SES may have an important independent influence on how children are raised and on how they develop over time. As such, researchers should separately measure income, education, and occupational status and use analytic techniques that are capable of identifying the potentially unique associations each has with human development.

\section{Contribution of Parental Involvement toward to Students'}

\section{Achievement}

The findings of the research reveal that path coefficient of 1.177 indicates no significant contribution of parental involvement towards students' English achievement. One possible explanation for this insignificant constribution might be the fact that parental involvement contribute indirectly to students' English achievement. For example, Lee (1994) utilizes NELS: 88 data to examine the effects of family involvement on a variety of educational outcomes in addition to achievement test scores. This study reveals that the effects of parental involvement in high school may be stronger on students' behavior, attitudes toward school, and report card grades than on achievement test scores. The study reports a number of noteworthy effects of different types of family involvement on tenth graders' attitudes and behaviors, after controlling for students' socioeconomic background, family structure, and previous educational characteristics. 
Furthermore, although some literature advocating involvement asserts that parental involvement has significant positive consequences for children (Ho and Willms, 1996), this does not guarantee that all types of parental involvement will be beneficial for all children. While it is important to know how, the types and to what extent parental involvement behaviors bolster student learning, it is equally critical to know how, the types and to what extent parental involvement behaviors may impede student learning. For instance, Lareau and Shumar (1996) reported that the emphasis on homework sometimes strains parent-child relations and introduces severe conflicts and tension in the home.

It is apparent then that, not all parental involvement behaviors, such as behavioral supervision, are appropriate. Behavioral supervision has shown either no association or a negative relationship with academic achievement (Catsambis, 2008). Firm disciplinary practices were found to be unrelated to a child's academic success (Miliotis et al., 1999), based on a sample of 59 6-11year-old African Americans from homeless families. And McNeal (1999) showed that parental involvement in the form of supervision generally explained behavioral outcomes (e.g., truancy) $(\beta=-.11, P<.01)$ but not cognitive outcomes (e.g., science achievement), and had greater effects for more affluent White students $(\beta=-.13, P<.01)$ than for less-advantaged students of any other race.

It is also obvious then that how, the types and to what extent parental involvement dimensions are implemented are other aspects of concerns. Rules in the home (rules on homework, GPA, TV, friends, etc.) is an example. That is, if the child perceives that parents have rules about watching television, and going out with friends, there is a positive relationship to achievement. However, if the parent reports having rules in the home-such 
as maintaining grade average, doing homework, and being responsible for certain household chores - there is a negative relationship on achievement. Similarly, there is an opposite relationship involving the variable talking about school. From the students' report, this represents a positive relationship to math achievement, but from the parents' report, this represents a negative relationship.

Desimone (1999) further examined the data in terms of ethnicity and reported some interesting patterns of predictor variables. For example, the variable talk with father about school showed a positive relationship to math achievement for Asian children, a negative relationship for Black and Hispanic students, and no significant relationship for White students. The variable rules on homework, chores, TV, and so forth was positively related to math achievement if reported by Asian children and negatively associated with math achievement if reported by White parents. Finally, the variable parents check homework from the students' perspective has a significant negative association with achievement across all ethnicities.

\section{Contribution of Family Background to Students' Achievement through the Mediating Factor of Parental Involvement}

The indirect effect of family background to students' achievement through the mediating factor of parental involvement is not significant with $p$-value of .47 . That is, $+/-1.28$ are the critical values of the test ratio which contain the central $90 \%$ of the unit normal distribution. This insignificant contribution can be traced to the guidelines implying that mediation can be said to occur when (1) the IV (Independent Variable) significantly affects the mediator, (2) the IV significantly affects the DV (Dependent Variable) in the absence of the mediator, (3) the mediator has a significant unique effect on the DV, and (4) the effect of the IV on the DV shrinks upon the addition of 
the mediator to the model. These criteria can be used to informally judge whether or not mediation is occurring. In this study, guidelines number 2 and 3 are not met.

\section{Predictors of Parental Involvement}

Aspiration and Expectation along with enhancing learning opportunities at home have the strongest effects on students' achievement. By far, parental encouragement for has the strongest positive effects on the test scores. This variable is a composite of four indicators of parents' expectation, provision of academic pressure, tutoring their children at home, and parents' support and encouragement. This corroborates with the study conducted by Fan and Chen (2001) revealing that parental aspiration/expectation for children's education achievement has the strongest relationship, whereas parental supervision has the weakest relationship with students' academic achievement. In addition, the relationship is stronger when academic achievement is represented by a global indicator (e.g., GPA) than by a subject-specific indicator (e.g., math grade).

Furthermore, aspiration and expectation in many parental involvement research studies is generally shown to have a positive relationship to academic achievement. For example, parental aspirations/expectations is the strongest dimension in the Fan and Chen (2001) meta-analysis examining effects on academic achievement (overall $r=.40)$, as well as the strongest predictor $(\beta=.28)$ in the Singh et al. (1995) structural equation modeling study. Parental expectations also has the largest effect size $(d=.88)$ and is one of the strongest predictors in determining 
academic achievement $(P<.001)$ in Jeynes' (2007) meta-analysis on parental involvement variables.

\section{CONCLUSION}

The conclusion that parental involvement has positive effects on students' achievement is corroborated by several literature reviews. Parental involvement correlated highly with student achievement. However, simply involving parents at home was not enough to improve a school's average level of achievement. In order for the school as a whole to benefit, parents must also be involved at school. Put simply, how, the types, and the extent of parental involvement determine how well it correlates with achievement, and that a combination of home and school involvement seems to be the most effective.

Even though the research found no significant contribution of parental involvement to students' English achievement, it does not suggest then that parental involvement is unimportant or ineffective. Also, there is no intention to vilify or cast roles of parents. The intention is to open the minds of those responsible for advocating parental involvement. In so doing, the possibility of negative consequences of parental involvement may be minimized or eliminated.

\section{REFERENCES}

Banerjee, M., Harrell, Z. A. T., \& Johnson, D. J. (2011). Racial/ethnic socialization and parental involvement in education as predictors of cognitive ability and achievement in African American children. Journal of Youth and Adolescence, 40(5), 595-605.

Bhatia, M. (2010). Childhood education. Jaipur: ABD Publishers. 
Bowden, H. W., Sanz, C., \& Stafford, C. A. (2005). Individual differences: Age, sex, working memory, and prior knowledge. In Sanz, C. (Ed.), Mind and context in adult second language acquisition: Methods, theory and practice (pp.105-140). Washington, DC: Georgetown University Press.

Breault, D. A., \& Allen, L. A. (2008). Urban education: A handbook for educators and parents. London: Greenwood Publishing Group, Inc.

Butler, R. (2000). What learners want to know: The role of achievement goals in shaping information seeking, learning, and interest. In Sansone, C., \& Harackiewicz, J. M. (Eds.), Intrinsic and extrinsic motivation: The search for optimal motivation and performance (pp.166-190). San Diego: Academic Press.

Caro, D. H. (2009). Socio-economic status and academic achievement trajectories from childhood and adolescence. Canadian Journal of Education. 32(2), 558-590.

Casanova, F. P., Garcia-Linares, M.C., Torre, M.J., \& Carpio, M.V. (2005). Influence of family and socio-demographic variables on students with low academic achievement. Educational Psychology. 25(4), 423435 .

Catsambis, S. (2008). Expanding knowledge of parental involvement in secondary education: Effects on high school academic success (Report No. 27). Queens College: CUNY.

Chasek, A. S., and Rosen, M. (2011). Instilling a Love of Learning at Home. Education Digest: Essential Readings Condensed for Quick Review, 77(1): 57-61.

Cheung, S. Y., \& Andersen, R. (2003). Time to read: Family resources and educational outcomes in Britain. Journal of Comparative Family Studies, 34(3), 413-415.

Christenson, S. L., Godber, Y., \& Anderson, A. R. (2005). Critical issues facing families and educators. In Patrikakou, E. N., Weissberg, R. P., Redding, S. \& Walberg, H. J. (Eds.), School-family partnerships for children's success (pp.21-39). New York: Teachers College Press. 
Cohen, L., Manion, L., and Morrison, K. (2007). Research methods in education. New York: Routledge.

Coleman, J. S. (1990). Foundations of social theory. Cambridge: Harvard University Press.

Conger, R., \& Conger, K. (2008). Understanding the processes through which economic hardship influences families and children. Handbook of Families and Poverty. SAGE Publications. Retrieved from http://sageereference.com/view/hdbk_familypoverty/n5.xml>.

Desforges, C., \& Abouchaar, A. (2003). The impact of parental involvement, parental support and family education on pupil achievement and adjustment: Research report 433. London: Department for Education and Skills.

Desimone, L. (1999). Linking parent involvement with student achievement: do race and income matter? The Journal of Educational Research, 93(1), $11-30$.

Fan, X. \& Chen, M. (2001). Parental involvement and students' academic achievement: a meta-analysis. Educational PsychologyReview, 13(1), 122.

Ghozali, I. (2011). Model persamaan struktural, konsep dan aplikasi dengan AMOS 19.0. Semarang: Badan Penerbit Universitas Diponegoro.

Grant, K. B., \& Ray, J. A. (2010). Home, school and community collaboration: culturally responsive family involvement. Los Angeles: Sage Publication.

Graves, S. L., \& Wright, L. B. (2011). Parent involvement at school entry: A national examination of group differences and achievement. School Psychology International, 32(1), 35-48.

Grolnick, W. S., Benjet, C., Kurowski, C. O., \& Apostoleris, N. H. (1997). Predictors of parent involvement in children's schooling. Journal of Educational Psychology, 89(3), 538-548.

Henderson, A. T., \& Mapp, K. L. (2002). A new wave of evidence: The impact of school, family and community connections on student achievement. Austin, TX: Southwest Educational Development Laboratory. 
Henry, K. L., Cavanagh, T. M., \& Oetting, E. R. (2011). Perceived parental investment in school as a mediator of the relationship between socio-economic indicators and educational outcomes in rural America. Journal of Youth and Adolescence, 40(9), 1164-1177.

Ho, E., \& Willms, J.(1996). Effects of parent involvement on eighth-grade achievement. Sociology of Education, 69(2), 126-141.

Hoover-Dempsey, K. V., Walker, J. M. T., Sandler, H. M., Whetsel, D., Green, C. L., Wilkins, A. S., et al. (2005). Why Do Parents Become Involved? Research Findings and Implications. Elementary School Journal, 106(2), 105-131.

Hornby, G. (2011). Parental involvement in childhood education: building effective school-family partnerships. New York: Springer Science+Business Media, LLC.

James, M.L. (2008). Parent involvement in their child's education. (Unpublished doctoral dissertation). Capella University, Minnesota

Jaynes, W. H. (2011). Parental involvement and academic success. New York: Routledge.

Jeynes, W. H. (2003). A meta-analysis: The effects of parental involvement on minority children's academic achievement. Education and Urban Society, 35(2), 202-218.

Jeynes, W. H. (2005). A meta-analysis of the relation of parental involvement to urban elementary school student academic achievement. Urban Education, 40(3), 237-269.

Jeynes, W. H. (2007). The relation between parental involvement and urban secondary school student academic achievement: A meta-analysis. Urban Education, 42(1), 82-110.

Katz, I., Kaplan, A. \& Buzukashvily, T. (2011). The role of parents' motivation in students' autonomous motivation for doing homework. Learning and Individual Differences, 21(4), 376-386.

Lareau, A., \& Shumar, W. (1996). The problem of individualism in familyschool policies. Sociology of Education. 69, 24-39. 
Lee, S. (1994). Family-school connections and student's education: Continuity and change of family involvement from the middle grades to high school. (Unpublished Doctoral dissertation). Johns Hopkins University, Baltimore, MD.

McBride. B. A., Schoppe-Sullivan, S. J. \& Ho. M. (2005). The mediating role of fathers' school involvement on student achievement. Applied Development Psychology, 26, 201-216.

McIntosh, J. (2008). Family background, parental involvement, and academic achievement in Canadian schools. Journal of Economic Literature. Economics Department, Concordia University.

McNeal, Ralph B. (1999). Parental involvement as social capital: differential effectiveness on science achievement, truancy, and dropping out. Social Forces, 78(1), 117-144.

Miliotis, D. A., Sesma Jr., \& Masten, A. S. (1999). Parenting as a protective process for school success in children from homeless families. Early Education \& Development, 10(2), 111-133.

Ogoye-Ndegwa, C., Mengich, W. S., \& Abidha, O. (2007). Parental participation in pupils' homework in Kenya: In search of an inclusive policy. International Education Journal, 8(1), 118-126.

Rachmajanti, S. (2005). The impact of the teaching of english at the elementary schools on the students' achievement of english at the first year of lower secondary school. (Unpublished Dissertation). State University of Malang, Malang.

Reynolds, A.J. (1992). Comparing measures of parental involvement and their effects on academic achievement. Early Childhood Research Quarterly, 7, 441-462.

Shannon, S.M. (1996). Minority parental involvement: a mexican mother's experience and a teacher's interpretation. Education and Urban Society, 29(1), 71-84.

Singh, K. et al. (1995). The Effects of Four Components of Parental Involvement on Eighth Grade Student Achievement: Structural Analysis of NELS-88 Data. School Psychology Review, 24, 99-317.

Stewart, E. (2008). School structural characteristics, student effort, peer association and parental involvement, the influence of school-and 
individual-level factors on academic achievement. Education and Urban Society, 40(2), 179-2004. 